\title{
SLUM SETTLEMENT PHENOMENON IN MEDAN CITY (CASE STUDY: KAMPUNG AUR, MEDAN MAIMUN DISTRICT)
}

\author{
Novida Yenny, Rohani, Kamarlin Pinem, Nabila Anggraini \\ Departement of Geography Education, Faculty of Social Science, Universitas Negeri Medan, Medan, Indonesia \\ *Corresponding Author: novidayennygeo@gmail.com
}

\begin{abstract}
Kampung Aur settlement is one of the slums of 18 villages determined based on Medan Mayor Decree No. 640/039.K / I/2015, with a very poor slum level, 3.49 Ha slum area and 307 households. Location Slums are scattered in various areas in Medan City, including along the river banks, along railroads, port areas, industrial areas, trade areas, and border areas of Medan City. The focus of the study was the slums of Kampung Aur, Medan Maimun District and the reluctance of residents to be relocated. The research objectives are; to find out the factors that cause the reluctance of relocation of residents of slums in Kampung Aur, Medan Maimun District, Medan City. The research method used a qualitative descriptive. The results of research on the reluctance of residents due to relocation of several factors, among others; 1) Settlement that has been passed down from parents has finally become the basis for residents to claim their legal presence in agararia, 2) the location of Kampung Aur which is near and downtown such as offices, restaurants and others that are very supportive for the economic activities of citizens, 3) the high family ties between residents supported by the same ethnic / ethnic origin, and a sense of shared destiny, 4) basic housing services that are deemed sufficiently adequate such as access to and out of villages, roads that connect between RTs, available clean water facilities, and electricity servis, 5) there are facilities and infrastructure that can meet the needs of citizens to socialize with each other and strengthen family relationships.
\end{abstract}

Keywords: Slums; Settlement; Phenomenon.

\section{INTRODUCTION}

The phenomenon of slums is often faced by almost all major cities in Indonesia, even large cities in other developing countries. This is the most difficult challenge each year for the government in overcoming the problems of slums in Indonesia. This is evidenced by the vast increase in slums in Indonesia, where REI (Real Estate Indonesia) recorded a slum area in 2014 was 38,000 hectares, increased to 87,000 hectares in 2019. Slum Settlement can be seen from the three characteristics. First, observable physical condition of the building is very tight conditions with low construction quality, the road network is not patterned and is not amplified, general sanitation and drainage are not functioning as well as the trash has not been managed properly. Second, the socio-economic conditions of the culture of the community residing in the settlement which included low income levels, loose social norms, a culture of poverty that colors his life which among others is evident from apathetic attitudes and behavior. Third, the impact of the two aspects of these indicators, such as can result in poor health conditions, sources of pollution, sources of the spread of disease and deviant behavior, which affects the overall life (https://trtb.pemkomedan.go.id/artikel-1027-permukimankumuh-dan-oper-penangannya.html).

According to Law No. 1 Article 1 Paragraph 13 of 2011 concerning housing and settlement areas, explained that slums are settlements that are not livable due to irregularity of buildings, high level of building density, and the quality of buildings and facilities and infrastructure that do not meet the requirements. In short, slum housing is housing that has decreased the quality of its function as a residence (Law No. 1 Article 1 Paragraph 13 2011). In general, slums in urban areas are in the middle of the city but are hidden from the environment that is usually passed by the general public. This can be in the form of slums or squatter slum areas. So that the slums make the city face environment does not healthy accompanied by poor environmental sanitation.Slums are referred to as illegal settlements if they are on buildings or land that is not owned by the state for settlement, such as on the banks of a river, on the banks of a railroad, under a flyover, in city parks and open land other green.

In Law Number 1 of 2011 concerning Housing and Settlement Areas, it has actually been explained about the prohibition for anyone to make settlements on the equivalent of a railroad track, this is stated in Article 140 which reads: "Everyone is prohibited from building, housing, and / or settlement in a place that could potentially cause danger to goods or people. "means that: what is meant by" places that could potentially cause danger include, railroad border, under the bridge, the area of Extra High Voltage Airways (SUTET), Regional River Border (DSS), disaster-prone areas, and special areas such as military zones. However, the existence of Law Number 2011 concerning Housing and 
Settlements has yet to run optimally. In fact, the Law has explicitly contained a prohibition on the establishment of settlements that do not have a settlement permit.

Rahmadi (2009), explained that specifically in handling squatters (settlements on illegal land) both in urban and outside urban areas, any building that stands up is recommended to be moved / relocated to a safer location in accordance with the existing spatial plan except construction or facility activities related to irrigation or infrastructure in the public interest (Rahmadi, 2009). If the eviction is considered as the last solution that must be done, then this effort also has procedures that must be carried out, so that the impact can be minimized. The eviction solution will almost certainly be accompanied by relocation or resettlement efforts. However, until now the relocation efforts that the government intends to do have never been going well. Even though the government already has a strong legal basis for relocation. The powerlessness of the government in dealing with slum communities needs to be questioned. The community seems to have great power that can compete with the power of law, even though the community is positioned as a violator of the law.

Medan city with an area of 265, $10 \mathrm{~km} 2$ (26510 ha) consists of 21 districts and 151 villages with a total number of 520,343 households and a population of 2,121,053 people (BPS North Sumatra, 2018) [4]. Medan City are in third place in the largest city in Indonesia after Jakarta and Surabaya, which is experiencing the problem of slums with the same characteristics as other areas. Where settlement slum in the city of Medan is located in the 17th District of the largest in 48 villages, with an area of settlement slum of 628, 60 ha or $2.37 \%$ of the area of Medan (Pinem, 2011). Slum settlements in Medan are on the banks of the river, along the railroad tracks, the port area, the industrial area, the trade area, and the periphery area. Judging from the distribution of slum locations, slums should be moved or displaced. Therefore, this study will examine the phenomena and characteristics of slums in one of Medan City areas, namely Aur Village, Aur Village, Medan Maimun District, which is included in the distribution of slum locations in Medan City (a case study). And analyze the causes of the existence of slums in the area.

\section{LITERATURE}

\subsection{Slums}

Slums in essence can be a slum or squatterareas. Cities in Indonesia population growth is not matched by the construction of urban facilities and infrastructure and the improvement of urban services, even what happened was that some urban areas experienced environmental degradation that could potentially create slum areas .As a result, slum areas (slums) appear in several areas of the city and it is unavoidable that is not planned by the government, but these slum areas (slums) grow naturally.It is different from the definition of squatter areas which means a public area or government property that is not allowed to be inhabited.So the squatter areas are known as wild slums. UN HABITAT (UN Agency) defines slums as an association and individuals who live under one roof in an urban area that lacks one or more of the following things (UN-Habitat, 1982).

a. Settlements that can survive in extreme climatic condition.

b. Adequacy of space in housing, which means no more than 3 people share the same space.

c. Easy access to clean water at affordable prices.

d. Access to adequate sanitation by providing private or public toilets with restrictions on the number of users.

e. A sense of security of land and building property rights that can prevent residents from forced evictions.

According to Rindrojono, (2013) Slums are a general picture about attitudes and low behavior seen from living standards and low income. In other words, slums can be interpreted as signs or a stamp given by the upper class already established to the group bottom which is not yet well established (Rindarjono, 2013).

\subsection{Characteristics and Criteria for Slums}

According to Budiharjo (2011), the characteristics of slums can becaused by housing factors and infrastructure factors. Besides the criteriaimprovement of slums can be seen from social symptoms and physical symptoms (Rindarjono, 2009).

a. Slum Settlement Characteristics

1) Semi permanent and non permanent housing factors.

2) Irregular layout.

3) Building status generally does not have a building permit.

4) High density of buildings and population.

5) The condition of the building is unfit for habitation and the distance between buildings is tight.

6) Lack of health of the neighborhood.

7) Infrastructure factor (accessibility / road, drainage, clean water, wastewater, and garbage).

b. Criteria for improvement of slums

1) Social symptom (low social life, very low socio economic status, the level of education is very low, and population density is very high.)

2) Physical symptoms (the average building condition is below the minimum standard, generally a village with non-permanent and semi-permanent buildings has reached the age of 10 years, high building density, very 
minimum open space and distance between buildings, the condition of physical facilities is below the minimum standard, areas that are heavily affected by flooding, and regional conditions require regulation in terms of land use).

\section{RESEARCH METHOD}

\subsection{Research Approaches}

This research was conducted deductively, so researchers departed from theory to go into the field in searching for data which could then be used in examining what factors influence the existence of slum areas in Kampung Aur, Aur Village, Medan Maimun District, Medan City. This study uses a qualitative descriptive approach to analyze existing problems.

\subsection{Population and Research Samples}

The population in this study is the people of Kampung Aur, Medan Maimun District, Medan City. The selection of informants with certain social considerations, which is done purposively, is based on what is known about the situation and conditions in Kampung Aur settlement. The sample used for this study was only 10 respondents. The criteria for informants in this study are people who have lived in the study site for more than 5 years, plus the village head, RT and community leaders and related parties, this shows the informant is very familiar with the problems and facts of the community.

\subsection{Research Location and Time}

The location of the research was conducted in Kampung Aur Village, Medan Maimun District, Medan, North Sumatra, where settlements were located around the Deli River. The slums are included in the category of squatters areas. The time of the study is about 6 months from starting licensing, research and sampling in the field, to the preparation of the final report.

\subsection{Data Collection Techniques}

One of the characteristics of qualitative research is humans as tools or instruments (Moleong, 2010) (Rindarjono, 2009). So to get the data/information done by observation, in-depth interviews, and study documents as supporting research.

\subsection{Data Analysis}

The analytical method in this study is to determine the factors that cause the existence of slums by using inductive analysis as the main basis for studying various data obtained based on a grounded theory approach. This approach has three basic elements that are interrelated with one another. The process of obtaining a theory is obtained from the flow of concepts, not existing data. While the concept is obtained through existing conceptualization data. On the other hand, the category is the beginning of the process of developing a theory which is higher than the concept. While propositions show the relationship between the concepts of Struss and Corbin (1990).

\section{RESULT OF RESEARCH}

Kampung Aur settlement is a slum area determined by the Mayor of Medan through Decree No.640/039.K/I/205 and this condition can be seen in plain view (Medan Mayor Decree No.640 / 039.K / I / 205). The housing conditions that are narrow, close together, with a small size $( \pm 4 \times 6 \mathrm{~m} 2)$ have one room that is inhabited by an average number of family members of more than 4 people, and does not meet proper living standards. The existence of Kampung Aur Settlement is a part of the past history that continues along with the development of Medan City and the population that lives in Kampung Aur goes on for generations. Kampung Aur located in Medan Maimun District. Medan Maimun Regency is located near the center of Medan City, consisting of six Kelurahans, there are Kel. Aur, Ex. Hamdan, Ex. Jati, Kel Kampung Baru, Kel Sei Mati and Kel.Suka Raja, with an area of around 3,342 km².

Kampung Aur has 10 wards, each of which is headed by a circle Head. Kampung Aur settlement is famous in Medan with various problems stored in it. Physically seen as settlements that are not much different from each other, it looks dirty and crowded. This condition is most likely due to the almost equal economic level of the community, which is mostly classified as poor. 


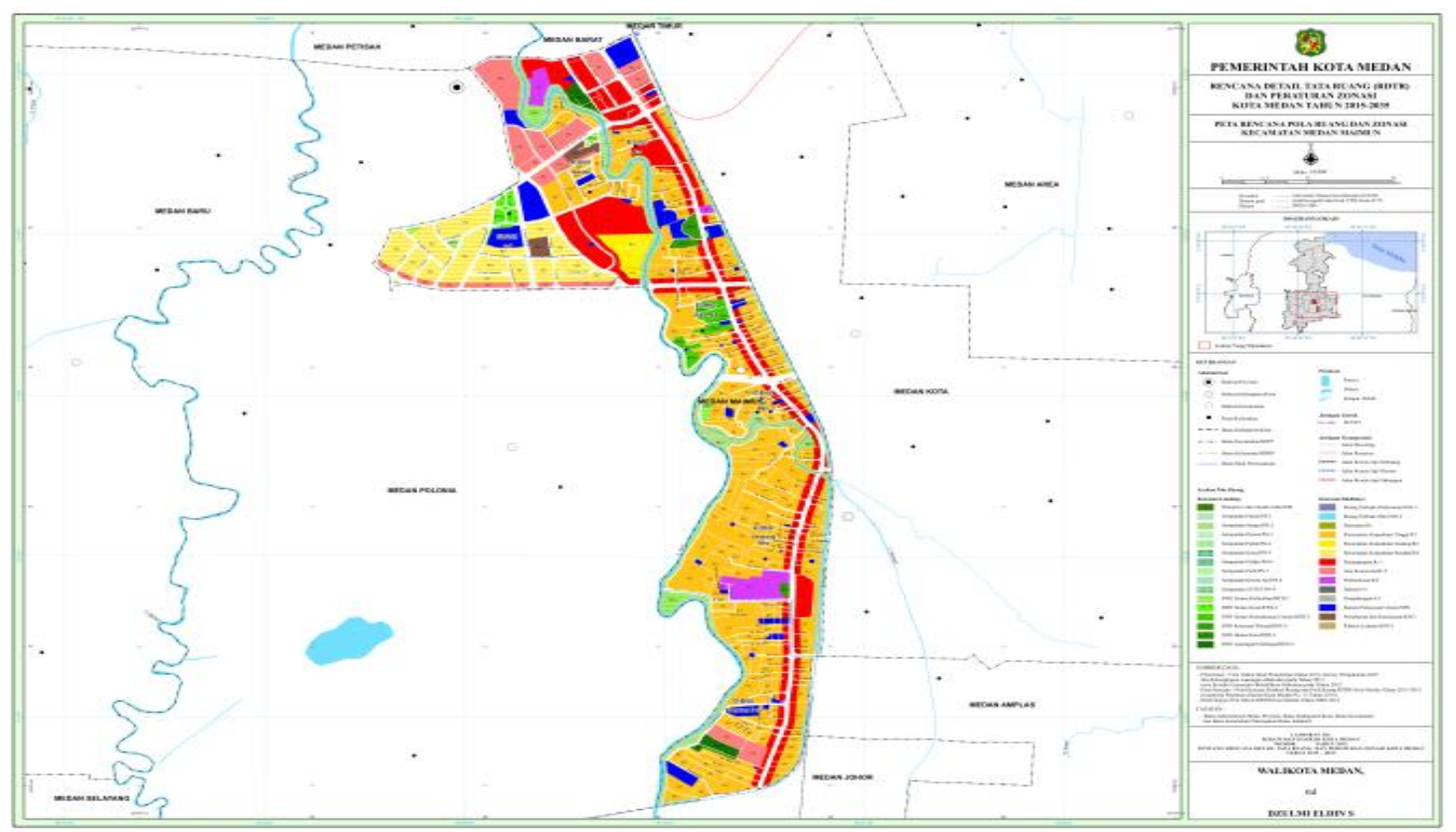

Figure 1. Map of The Maimun Terrain Spatial Plan.

\subsection{Physical Environmental Characteristics of Kampung Aur}

Table 1. Characteristics of Settlement Residents of Kampung Aur.

\begin{tabular}{|c|c|c|}
\hline No & Character of Settlement & Information \\
\hline 1 & Ownership status & $\begin{array}{l}-80 \% \text { of those who live on the edge of the river are their } \\
\text { own property, with land status without certificates, owned } \\
\text { from generation to generation from parents, }(60 \% \text { occupied } \\
\text { by the owner and } 40 \% \text { leased) } \\
\text {-The } 10 \% \text { located at the top are certified privately owned, } \\
\text { generally of Chinese descent. } \\
-65 \% \text { of the people living on the banks of the railroad } \\
\text { tracks are their own property without certificates, } 35 \% \text { are } \\
\text { tenants. }\end{array}$ \\
\hline 2 & House type & $\begin{array}{l}\text {-Permanent house }=15 \% \\
\text {-Semi permanent }=35 \% \\
\text {-Emergency house }=50 \%\end{array}$ \\
\hline 3 & House condition & $\begin{array}{l}-90 \% \text { of houses located near riverbanks are not suitable for } \\
\text { habitation (house size Lk. } 18 \mathrm{~m}^{2} \text {, average room } 1 \text { plus a } \\
\text { multi-function living room, modest minimum). } \\
-95 \% \text { of the houses located on the upper part of the river } \\
\text { are livable. } \\
-85 \% \text { of the houses located on the banks of the railroad } \\
\text { uninhabitable. Lk. } 18 \mathrm{~m}^{2} \text { house size, an average of } 1 \text { room } \\
\text { plus a living room multi-functional, sober MCK). }\end{array}$ \\
\hline 4 & Ethnic / ethnic group & $\begin{array}{l}-75 \% \text { of the riverbanks are Minang, } 16 \% \text { Javanese, } 14 \% \\
\text { Malay etc. } \\
-95 \% \text { located at the top of the Deli river are ethnic Chinese. } \\
-70 \% \text { of the houses are located on the banks of the Mnang } \\
\text { railroad and the rest are a mixture of Java, Malay, Nias, } \\
\text { Batak. }\end{array}$ \\
\hline 5 & Population density & Solid \\
\hline 6 & Green open space & Almost no. \\
\hline
\end{tabular}

Source: Analysis of Primary and Secondary Data, 2019. 
Condition of Kampung Aur House:

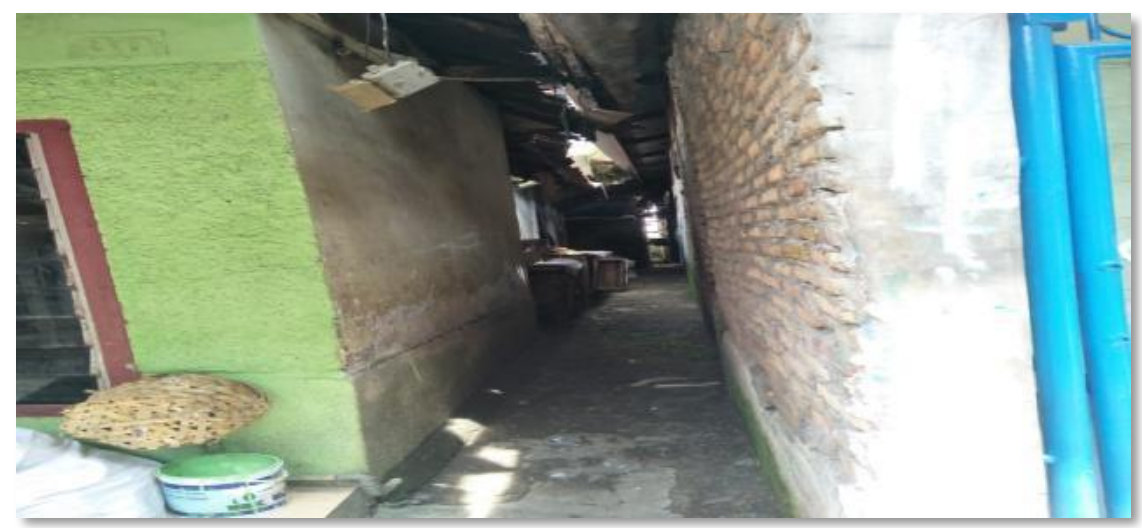

Figure 2. Narrow alley connecting each house.

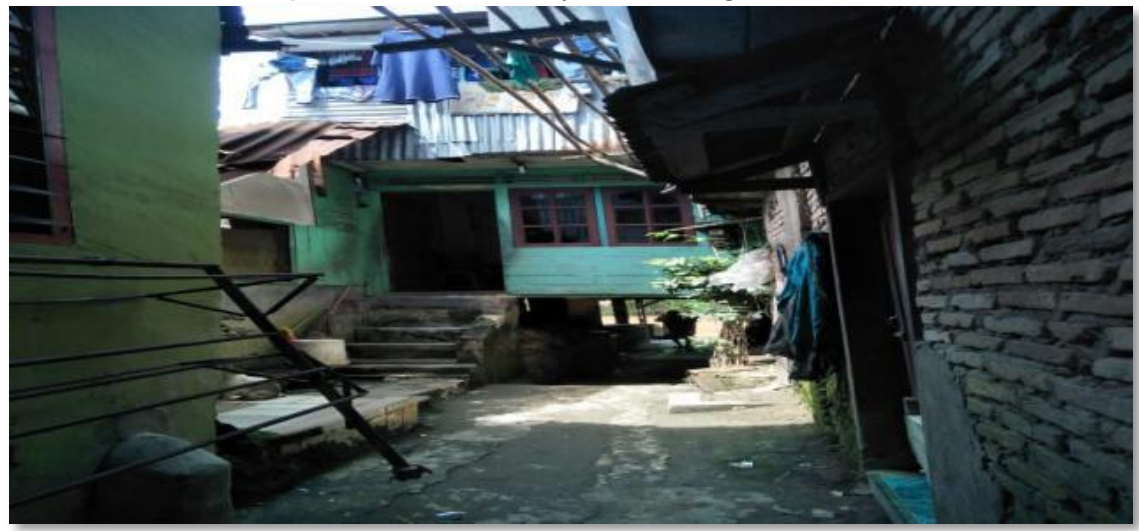

Figure 3. Layout of residents' homes that are layered and irregular.

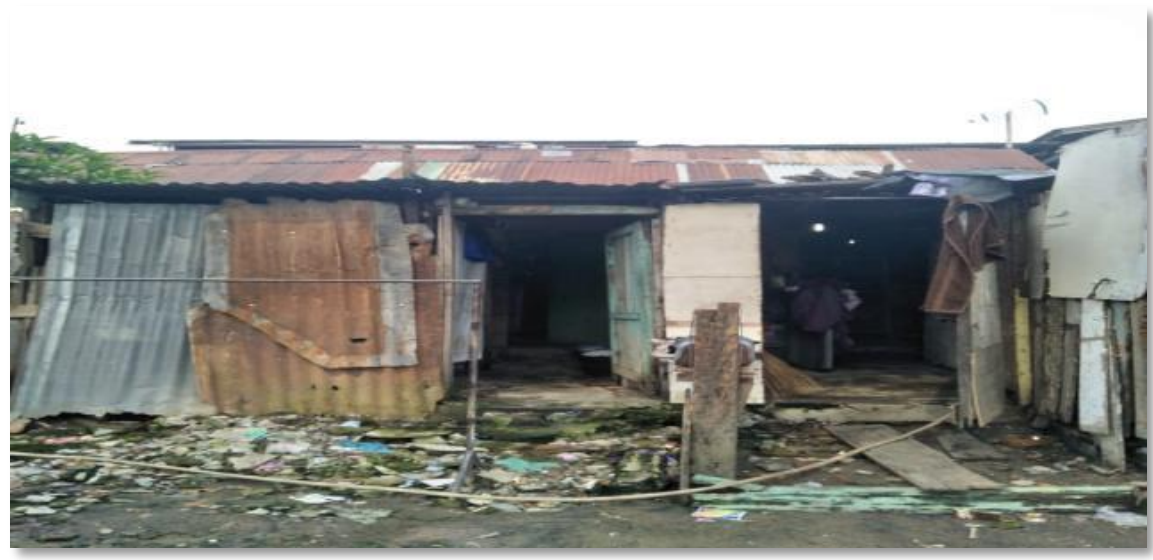

Figure 4. Conditions behind one of the houses of the residents, where residents do not have a household waste disposal channel.

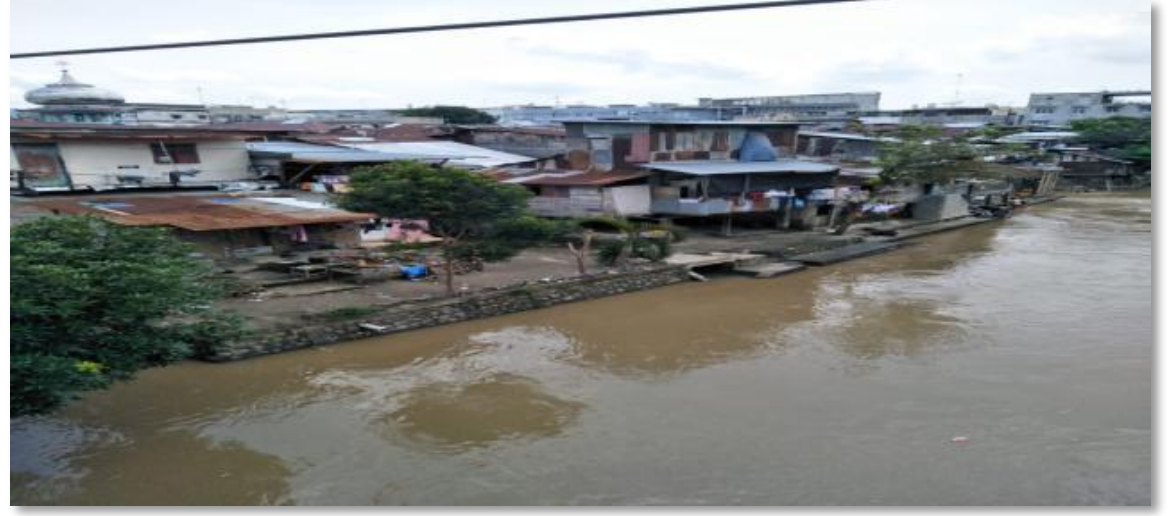

Figure 5. Circle IV view of Aur Village on the Deli River. 
Based on the character of the settlement in the table above, most of the houses near the Deli river are self-owned houses that have been owned by parents for generations, with ownership status without certificates and most of them are owned by Minang tribes, with unsuitable living conditions. Likewise, the settlement on the edge of the railroad tracks, it is also legally an illegal settlement whose land ownership is owned by PJKA, but residents make houses with the status of land for rent, and some residents are tenants. Unlike the residents who live in Kampung Aur, which is located at the top of Kampung Aur, bordering Jalan Brigjen Katamso, which is a legal (certified) settlement that is inhabited by most ethnic Chinese.

\subsection{Basic Settlement Services}

The basic services of the Settlement are supporting facilities that complement the Settlement which is at the same time acondition like a Settlement.The basic services of this settlementcan be seen in the following table:

Table 2. Basic Settlement Services

\begin{tabular}{|c|c|l|}
\hline No & \multicolumn{1}{|c|}{ Criteria } & \multicolumn{1}{c|}{ Information } \\
\hline 1 & Road condition & $\begin{array}{l}\text { Almost all residential roads } \\
\text { Pavement has been done with cement } \\
\text { (especially the main road which is adjacent to } \\
\text { the mosque). }\end{array}$ \\
\hline 2 & Clean water facilities & $\begin{array}{l}\text { Adequately, PDAM water channels has } \\
\text { entered every resident's home. But to avoid } \\
\text { costs large water payments (partial) great } \\
\text { citizens still do MCK activities on the river. }\end{array}$ \\
\hline 3 & Toilet & $\begin{array}{l}\text { All houses have septic tanks and drainage } \\
\text { pipes which leads to the river. }\end{array}$ \\
\hline 5 & Electricity facility & $\begin{array}{l}\text { Adequate every day } \\
\text { Inadequate, because not all locations have } \\
\text { landfills still seen scattered on house } \\
\text { residents' houses. And there are still some } \\
\text { residents made the river as a final dump the } \\
\text { rubbish. }\end{array}$ \\
\hline 6, & Drainage ditch & $\begin{array}{l}\text { The drainage of household waste water is not } \\
\text { good, because there is no good drainage. }\end{array}$ \\
\hline
\end{tabular}

Source: Secondary Data Analysis, 2019.

The table above shows that the road which is the access of residents between the alleys has not all beenhardened, but for roads that connect between environments, hardening has been done with cement.The existence of a road between the alley connecting the Settlement with the river is partly still a dirt road, as well as the water channel that is still open to the river gives the impression of slums and unpleasant odors. Domestic wastewater, especially those dealing with rivers, is discharged into rivers, not to mention garbage that has not been properly managed.

\subsection{Public facilities and infrastructure supporting settlement}

Facilities and infrastructure Settlement is one of the supports to the realization of good settlement. Facilities and infrastructure also function as communal space, which is a space that accommodates various social activities that can be used by the community or community (Wijayanti, 2000). The existence of communal space willbe a place for people to gather indoing activities together, integrating each other, discussing, deliberation, social activities, and others. There are several facilities and infrastructure owned by the residents of Kampung Aur for joint activities, including the following:

Table 3. Supporting facilities and infrastructure.

\begin{tabular}{|c|l|l|}
\hline No & \multicolumn{1}{|c|}{ Amenities } & \multicolumn{1}{c|}{ Information } \\
\hline 1 & $\begin{array}{l}\text { The house of worship } \\
\text { also functions as a } \\
\text { landfill, also functions as } \\
\text { a closed communal } \\
\text { space }\end{array}$ & $\begin{array}{l}\text {-There are two houses of worship, the mosque in Kampur Aur } \\
\text { Dusun IV and in neighborhood 8 near the railroad street pawnshop. } \\
-3 \text { Catholic churches scattered around Jl Katamso. } \\
-1 \text { Bhuda Temple and Temple } \\
\text { This house of worship also functions as a closed communal space } \\
\text { such as meetings, discussions, etc. }\end{array}$ \\
\hline 2 & School & $\begin{array}{l}\text { Available, and the location is not too far from the neighborhood.Still } \\
\text { in one sub-district like SD, 1 private university. }\end{array}$ \\
\hline 3 & Field/park & Not available, settlement conditions are very crowded \\
\hline
\end{tabular}




\begin{tabular}{|c|l|l|}
\hline 4 & Market & $\begin{array}{l}\text { Available, and the location is not too far fromresidential } \\
\text { areas.Still in one district. }\end{array}$ \\
\hline 5 & $\begin{array}{l}\text { Hospital/clinic/ } \\
\text { posyandu. }\end{array}$ & $\begin{array}{l}\text { There are 7 Posyandu and clinics available in this settlement. } \\
\text { And the service is still categorized as good. }\end{array}$ \\
\hline 6 & Open public space & $\begin{array}{l}\text { Located in the yard of the house that functions as a place to sell, } \\
\text { and often used as a gathering place for residents, the mosque yard } \\
\text { becomes a means for children to play. }\end{array}$ \\
\hline
\end{tabular}

Source: Analysis of secondary data, 2019.

From the table above it can be seen that the facilities and infrastructure available to support the completeness of Settlements are sufficiently available even though they are inadequate.Many people use the mosque as a place of worship as well as a place of deliberation, and the mosque yard as a children's playground. Besides that, many yards of houses are used as places to sell daily necessities, and selling food which also functions as a place for people to gather to socialize.Family relations between residents are very close, they know each other, and help each other.

\subsection{Factor Causing the Existence of Slums (Relocation Reluctance)}

Based on the results of the research obtained through direct observation, interviews with residents, the Lurah and local RT and analysis of field datato obtain the characteristics of Settlement both social and physical, shows that there are major factors that make people in Kampung Aur reluctant to move or be relocated.These factors are among other things; 1) the length of time residents have lived in Kampung Aur which has been passed down from their parents and then passed on by their children which eventually became the basis for claiming their legal existence in agararia, and this was also reinforced by the UN levies they paid to Country. 2) the location of Kampung Aur near and downtown such as offices, restaurants and others that are very supportive for the economic activities of citizens, 3) the high level of family ties between residents supported by similarity of origin / ethnicity, and a sense of common sense, so that many choose to remain in Kampung Aur, 4) adequate basic settlement services such as access to and out of villages, roads that connect between RT, clean water facilities that are already available, and electricity service 5) the existence of public facilities and infrastructure to strengthen relations between residents to care for each other, please help so as to strengthen the familial relationship between citizens.

Based on the aforementioned factors, Kampung Aur will remain a choice of citizens, although the Medan city government wishes to relocate residents, but this has never been possible. This has been conveyed by the government to residents. According to information, thegovernment had planned to organize the settlement by making flats, but the residents wanted the arrangement without evicting or not in theform of flats.The desire of the government and citizenswill never be met, so this is a dilemma for both parties. One side of the government has the authority to make the city environment comfortable and safe for all citizens, but on the other hand of course citizens should abide by the rules according to applicable government rulesso that the existence of improper settlements does not cause problems for the environment and for the residents themselves such as flood hazards, because the riverbanks should be planted with trees as an antidote to abrasion and free from residential settlements/other buildings. Likewise with the suburbs of the railroad tracks whichare the land of PJKA which can be evicted at any time.

If seen from these factors, the arrangement that can be done to overcome the phenomenon of slums in Aur Village, Aur Village, Medan Maimun District, namely by handling area-based slum environment is to improve the quality of slums and slums in a coordinated and sustainable manner and integrated with integrated district / city spatial planning through the tridaya approach, as well as encouraging the creation of a habitable housing and settlement environment (Ruli \& Fadjarani, 2018). With the target of handling the area-based slum environment, among others (Ruli \& Fadjarani, 2018):

a) Implementation of the arrangement of slums and slums that are in accordance with the function of the area and city structure.

b) Achieving a reduction in the extent of slums and slums.

c) The realization of a society that can independently plan and implement efforts to improve the quality of slums and slums and maintain them.

\section{CONCLUSION}

Based on the findings and discussion of the results of research that have been carried out conclusions can be drawn as follows:

a. The people of Kampung Aur are dominated by Minang and Javanese, with the main livelihoods being private workers and traders, and the average level of community education is High Schools (SMA). 
b. Most of the inhabitants of Kampung Aur have lived for generations in the Kampung Aur area, so that a strong family bond is formed between the community and a high level of concern has become one of the reasons for reluctance to move or be relocated, coupled with the trust of the citizens regarding the status of home ownership which has been occupied for more than 20 years is considered legally valid in accordance with agrarian law even without a certificate, thus making people prefer to remain in Kampung Aur. Add to this the fact that the location of this settlement is close to the center of Medan.

c. The characteristics of the slums show that inadequate housing conditions, such as most types of impermanent buildings with one room plus a living room occupied by one family with 2-3 children at the same time, are not good enough for the growth and development of children, poor condition of septic tanks and household waste disposal pipes, and poor drainage conditions.

d. The basic services of these settlements are already quite good, such as access to main roads or neighborhood roads that are mostly already cemented, electricity facilities, and clean water services, although most people do not use these services due to cost issues. These settlements are also included in flood-prone areas when the rainy season arrives.

e. In addition to the poor condition of settlements, the legality of ownership of land and houses is unclear. These settlements are also included in areas prone to spreading drugs, so this environment is not safe for children.

f. People prefer to do environmental management without relocation of the population. So if seen from these factors, things that can be done to overcome the phenomenon of slums in Kampung Aur, Medan Maimun District that are in accordance with the conditions of the community is by structuring environmental-based slums.

\section{REFERENCES}

Administrator. (2017, July 17). "Slums and their mitigation efforts". Retrieved 11 10, 2019, from the Medan City Government Spatial Planning Office: https://trtb.pemkomedan.go.id/artikel-1027-permukiman-kumuh-danoper-penangannya.html

Law No. 1 Article 1 Paragraph 13 2011. About Perumahan dan Kawasan Permukiman .

Rahmadi, Deva Kurniawan. 2009. "River Basin Settlements: Discussion on the Arrangement of Waterfront Areas in the 5th edition of the Spatial Planning Bulletin", September - October 2009, Development of Coastal Areas and Waterside Areas. Jakarta: Secretariat of the BKPRN Implementation Team .

North Sumatra Central Statistics Agency, 2018.

Pinem, M. 2011. "Distribution of Kumuh Settlements in Medan City". Volume 3, Number 1. Journal of Geography. Medan State University.

UN-Habitat. 1982. Survey of Slums and Squatters. Dublin: Tycooly International Publishing Ltd.

Rindarjono, Mohammad Gamal. 2013. Slum Settlements in the Study of Slums in Perspectives. Yogyakarta: Mighty Media.

Budiharjo, Eko. 2009. Housing and Settlements in Indonesia. Semarang: PT Alumni.

Strauss, Anselm and Corbin, Juliet.1990. Basics of Qualitative Research: Procedures and Grounded Theory Techniques. Sage Publication.

Medan Mayor Decree No.640 / 039.K / I / 205

Wijayanti, S.2000. Setting Space Patterns Communal Social Interaction. (Thesis) Undip Architecture Now. Ruli, A., \& Fadjarani, S. (2018). "Regional Based Slum Settlements". Journal of Geography, 56-67. 